\title{
ポリウレタン系形状記憶ポリマーの形状回復および二次賦形特性*
}

$$
\begin{array}{lllll}
\text { 戸 伏 壽 昭*1, 林 } & \text { 俊 } \text { *2 }^{* 2} \\
\text { 星 尾 一 暢*3, 江 尻 佳 弘*4 }
\end{array}
$$

\section{Shape Recovery and Secondary-Shape Forming in Polyurethane-Shape Memory Polymer}

\author{
Hisaaki TOBUSHI ${ }^{* 5}$, Syunichi HAYASHI, \\ Kazumasa HOSHIO and Yoshihiro EJIRI \\ ${ }^{* 5}$ Department of Mechanical Engineering, Aichi Institute of Technology, \\ 1247 Yachigusa, Yakusa-cho, Toyota-shi, Aichi, 470-0392 Japan
}

\begin{abstract}
In shape memory polymers, large strain can be fixed at low temperature and thereafter can be recovered at high temperature. If the shape memory polymer is held at high temperature for a long time, the secondary-shape forming with irrecoverable strain appears. The secondary-shape forming can be applied to a new simple method of fabricating shape-memory polymer elements. In the present paper, the influence of the strain-holding conditions on shape recovery and the secondaryshape forming in polyurethane-shape memory polymer is investigated by the tension test for film and the three-point bending test for sheet. The higher the shape-holding temperature and the longer the shape-holding time, the higher the rate of secondary-shape forming is. The equation to express the rate of secondary-shape forming is formulated.
\end{abstract}

Key Words : Shape Memory Polymer, Shape Recovery, Shape Fixity, Secondary-Shape Forming, Polyurethane, Strain-Holding Condition

\section{1. 粕 言}

インテリジェント材料として注目されている形状記 憶材料の中で形状記憶ポリマー (shape memory polymer, SMP)は特に回復変形量が大きく, その応用が期待され ている(1)(2).SMPでは分子鎖の運動性能がガラス転移温 度 $T_{g}$ の上下の温度で異なるために, $T_{g}$ 以上の温度で変 形した形状が $T_{g}$ 以下の温度で保たれる形状固定性お よび固定された形状が加熱により元の形状に戻る形状 回復性を利用できる. 実用化されているポリウレタン 系 SMP の $T_{g}$ は室温 $\pm 50 \mathrm{~K}$ の温度範囲に設定可能であ $ろ^{(3)(9)}$.この為に SMP はエンジンのオートチョークエ レメント，身障者用のフォークハンドル，医療用留置

* 原稿受付 2007 年 3 月 7 日.

*1 正員, 愛知工業大学工学部 (函 470-0392 豊田市八草町八千 草 1247).

*2 (株) DiAPLEX (恶 150-0022 東京都淽谷区恵比寿南 1-5-2).

*3 正員, (株)中菱エンジニアリング (画 453-0862 名古屋市中 村区岩塚町九反所 60-1).

*4 学生員, 愛知工業大学大学院工学研究科.

E-mail : tobushi@aitech.ac.jp
針など広範用の分野で実用化されている.ポリウレタ ン系 SMPではシート, ビーズ，フォームなどの形態が 利用できる. 特に, フォームの場合には軽量で大きな 体積変化が利用できるため, 航空宇宙分野で衛星探査 機への応用が検討されている. この場合, 特に長期間 に亘り固定した形状が保持され，さらにその後に元の 形状に戻ることが必要である.

SMP フォームの長期間に亘る特性の研究によりひず み保持条件に依存して形状固定性およひ形状回復性が 完全ではなくなり，元の形状に戻らない二次賦形現象 (secondary-shape forming, SSF)の現れることが確認され た(の). したがって, SMP の熱・力学的特性を評価する 上でひずみ保持条件の形状回復性および二次賦形現象 に対する影響は重要である.一方, 二次賦形現象を SMP 素子を成形する観点から考えると, 複雑な形状の SMP 素子を単純な機構で成形加工できることになり, 有用 な成形法を開発できる可能性がある.

本研究においてはポリウレタン系 SMPに関して, 形 状回復と二次賦形に関する基本特性を調べるためにフ 
イルムに対する引張試験を行う。.また，実用上多く用 いられる曲げを受ける SMP 素子に関する特性を調べ るためにシートの 3 点曲げ試験を行う.これらの実験 により形状回復と二次賦形の特性を検討する. これら の現象に影響する主な因子には形状を保持するときの 温度, 時間およびひずみがある. 本研究では, これら の因子の影響を検討する. 短時間保持においては, $T_{g}$ 以下の保持温度の二次賦形特性と, $T_{g}$ 以上の保持温度 での保持温度と時間の増加に伴う非回復ひずみの挙動 を明らかにする. また, 実験結果に基づき二次賦形特 性を表す関係式を提案する.

\section{2 実検方法}

\section{1 供試材およひ試険片}

\section{(1) フィルム材}

引張試験の供試材は, 三菱重工業(株)製のポリウレタ ン系 SMP フィルム, ダイアリィ MM6520 であった. そ の厚さは $0.25 \mathrm{~mm}$ であった. 試験部の幅は $10 \mathrm{~mm}$, 引張 試験の標点距離lは 40mm であった. 試験片の両端の つかみ部はすべりが生じることなく, 正確に保持され る様に幅 $42 \mathrm{~mm}$, 長さ $33 \mathrm{~mm}$ とした. また, 動的粘弾 性試験により求めたガラス転移温度 $T_{g}$ は $338 \mathrm{~K}$ であっ た. 熱・力学的特性が大きく変化するガラス転移領域 は $T_{g} \pm 15 \mathrm{~K}$ の温度範囲である(

(2) シート材

曲げ試験の供試材は三菱重工業(株)製のポリウレタ ン系 SMP シート，ダイアリィMP9000であった。試験 片は厚さ $5.0 \mathrm{~mm}$, 長さ $60 \mathrm{~mm}$, 幅 $10 \mathrm{~mm}$ であった. 3 点曲け試験の支点間距離は $40 \mathrm{~mm}$ であった．また, 動 的粘弾性試験により求めたガラス転移温度 $\mathrm{T}_{\mathrm{g}}$ は $373 \mathrm{~K}$ であった.

2.2 実涂置 負荷・除荷と加熱・冷却の熱・力学 負荷は形状記憶材料特性試験装置 ${ }^{(8)}$ を用いて与えた. 本 装置は負荷・除荷を与える引張・圧縮試験機と温度を 制御する加熱・冷却装置から構成されている. 荷重は ロードセルにより検出した. 引張試験における標点間 の変位と曲げ試験における中央点のたわみはクロスへ ッドの変位により測定した. 温度は直径 $0.1 \mathrm{~mm}$ の熱電 対により測定した. 熱電対の先端は(1) フィルム引張試 験の場合は試験片中央部の表面近くに, (2) シート曲げ 試験の場合は試験中央部の押さえ具に配置した. 温 風・冷風は試験片に直接当たらない様に対流させた.

シートの曲げた形状を長時間保持する試験において は所定のたわみを与えた後に，その形状を保持するた めに形状固定治具を用いた. 形状を固定した試験片を 所定の温度で保持するために恒温炉を用いた.

\section{3 実唫手順}

\section{(1) フィルムの引張試険}

SMP フィルムの形状回復と二次賦形特性を引張り試 験により調べた. 実験ではひずみ速度 20\%/min で負荷 し, 最大ひずみ $\varepsilon_{m a x}$ は $30 \%$ および $50 \%$ とした. 次の手 順で引張試験を行った.

(1) $T_{g}+20 \mathrm{~K}$ においてひずみ速度 $20 \% / \mathrm{min}$ で最大ひずみ $\varepsilon_{\text {max }}$ を与える.

(2) 最大ひずみを保持し, 室温まで邻却する. したが って, 保持ひずみ后は $\varepsilon_{\max }$ と等しい.

(3) 冷却後, $\varepsilon_{h}$ を保持したまま所定の保持温度 $T_{h}\left(T_{h}=T_{g}\right.$ $\left.T_{g}+10 \mathrm{~K}, T_{g}+20 \mathrm{~K}\right)$ まで加熱する.

(4) 保持温度 $T_{h}$ で $g_{h}$ を所定の保持時間 $t_{h}\left(t_{\mathrm{h}}=0.5 \mathrm{~h}, 1 \mathrm{~h}, 2 \mathrm{~h}\right.$, $3 \mathrm{~h}, 4 \mathrm{~h}, 8 \mathrm{~h})$ )間保持する.

(5) 所定の保持時間 $t_{h}$ が経過した後, 除荷し無応力状 態にする.

（6) 無負荷の下で温度 $T_{g}+30 \mathrm{~K}$ まで加熱し, 形状を回復 させる.

\section{(2) シートの曲け試験}

SMP シートの形状回復と二次賦形特性を調べるため に2 種類の 3 点曲け試験を行った. 実験( i ) は短時間保 持の曲げ試験, 実験(ii)は長時間保持の曲げ試験であり, 以下に各実験方法を示す. 両方の実験において, たわ み速度 $\mathrm{d} y / \mathrm{d} t$ を $2 \mathrm{~mm} / \mathrm{min}$ とし，最大たわみ $y_{\text {max }}$ を $15 \mathrm{~mm}$ とした.

\section{(i) 短時間保持の曲1試釦}

(1) $T_{g}+20 \mathrm{~K}$ まで試験片を加熱した後, たわみ速度 $2 \mathrm{~mm} / \mathrm{min}$ で最大たわみ $y_{\text {max }}=15 \mathrm{~mm}$ まで押込む.

(2) 最大たわみ $y_{\text {max }}$ を保持しながら室温まで泠却する. したがって，保持たわみ $y_{h}$ は $y_{\text {max }}$ と等しい.

(3) 冷却後, $y_{h}$ を保持して所定の保持温度 $T_{h}\left(T_{h}=T_{g}\right.$ $\left.T_{g}+10 \mathrm{~K}, T_{g}+20 \mathrm{~K}, T_{g}+30 \mathrm{~K}\right)$ まで加熱する.

(4) 保持温度 $T_{h}$ で $y_{h}$ を所定の保持時間 $t_{h}\left(t_{h}=0.5 \mathrm{~h}, 1 \mathrm{~h}, 2 \mathrm{~h}\right.$, $4 \mathrm{~h}, 8 \mathrm{~h})$ の間保持する.

(5) 所定の保持時間 $t_{h}$ が経過したら, 押込み棒を引上 げ無負荷状態にする.

(6) 除荷後, 試験片を $T_{g}+20 \mathrm{~K}$ まで加熱し, 形状を回復 させる.

\section{(ii) 長時間保持の曲け試䤡}

(1)および(2)の過程は短時間保持の曲げ試験と同じであ る.

(3) 冷却後, たわみ $y_{h}$ の試験片を保持治具にはめて恒 温槽内に入れ, $y_{h}$ を保持したまま所定の保持温度 $T_{h}\left(T_{h}=T_{g}, T_{g}+10 \mathrm{~K}, T_{g}+20 \mathrm{~K}, T_{g}+30 \mathrm{~K}\right)$ まで加熱する.

(4) 保持温度 $T_{h}$ で $y_{h}$ を所定の保持時間 $t_{\mathrm{h}}\left(t_{\mathrm{h}}=18 \mathrm{~h}, 24 \mathrm{~h}\right.$, $48 \mathrm{~h}, 72 \mathrm{~h}, 96 \mathrm{~h})$ の間保持をする. 
(5) 所定の保持時間が経過したら，保持冶具を取り外 し無負荷状態にする.

（6) 除荷後, 試験片を $T_{g}+20 \mathrm{~K}$ まで加熱し, 形状を回復 させる。

\section{3. 実鍈㽞と考察}

\section{1 引張りにおける形状回復と二次珢形特性}

\subsection{1 応力ーひずみ一温度関係＼cjkstart実験結果の処理に}

おいて，応力とひずみはそれぞれ公称応力と公称ひず みで表した.ひずみは回復過程においても初期の標点 距離 40m に基づいて計算した. 実施結果を示す図中の 記号(1)-66は実験手順で示した負荷過程(1)-6)に対応す る.

（1）保持時間䍐しで除荷した場合の変形挙動 保 持ひずみ $\varepsilon_{h}=30 \%$, 保持温度 $T_{h}=T_{g}$, 保持時間 $t_{h}=0$ のフ イルムの引張試験で得られた応力-ひずみ曲線とひず み-温度曲線を図 1 (a)と(b)にそれぞれ示す。図1(a)から わかるように，保持ひずみ致を与え(1)，その後的を保持 して室温まで冷却する過程(2)において回復応力 $\sigma_{r}=5 \mathrm{MPa}$ が現れる. 回復応力は, 冷却過程においてひ ずみを保持するために熱収縮に伴う熱応力に基づいて 現れる(7). 加熱過程(3)および保持過程(4)(この場合, $\left.t_{h}=0\right)$

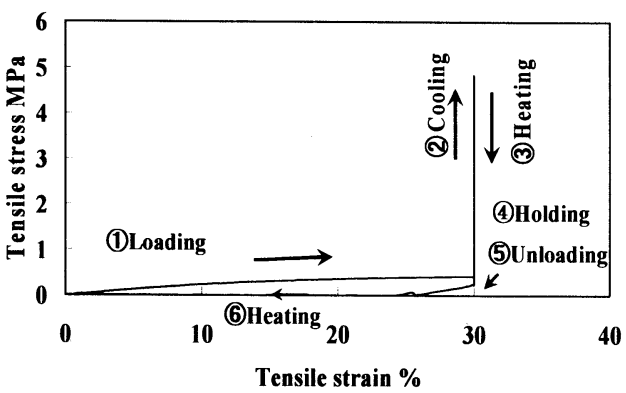

(a) Stress-strain curve

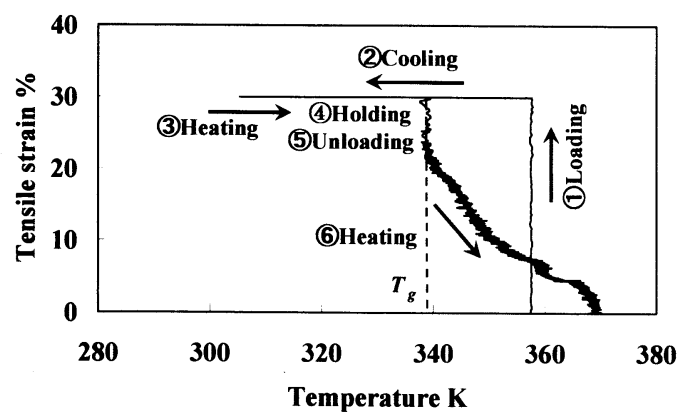

(b) Strain-temperature curve

Fig.1 Stress-strain curve and strain-temperature curve for $\varepsilon_{h}=30 \%, T_{h}=T_{g}$ and $t_{h}=0$ in tension
において応力は减少する. 除荷過程(5)においてひずみ は少し回復する. 無応力下での加熱過程66でひずみは 回復する. 図 1 (b)からわかるように, 無応力下の加熱 過程6においてひずみは温度の上昇に伴い徐々に回復 し， $T_{g}+30 \mathrm{~K}$ までの加熱で完全に回復する. ひずみの回 復は, $T_{g}$ 以上の温度で SMP の分子鎖の熱運動(ソフト セグメントのミクロブラウン運動)が活発になること により生じる.

(2) 高温で一定時間保持した軥合の变形挙動 保 持ひずみ $\varepsilon_{h}=30 \%$, 保持温度 $T_{h}=T_{g}+15 \mathrm{~K}$, 保持時間 $t_{h}=$ $2 \mathrm{~h}$ の引張試験で得られた応力-ひずみ曲線とひずみ-温 度曲線を図 2 (a)と(b)にそれぞれ示す。

図2(a)からわかるように, 応力-ひずみ曲線は図 1 (a) とほほ類似しているが，一定ひずみ歹の下での加熱過 程(3)およひ保持過程(4)において応力は非常に小さくな る. 図 2 (b)からわかるように, 無応力下の加熱過程(6) においてひずみは温度の上昇に伴い徐々に回復するが, $T_{g}+30 \mathrm{~K}$ までの加熱で 7\%のひずみ( SMPを $T_{g}$ 以上の温度でひずみを保持すると分子鎖のミ クロブラウン運動に基づき分子配向が進み, 元の形状 に完全には戻らなくなる(9).これにより二次賦形現象が 起きていることがわかる.

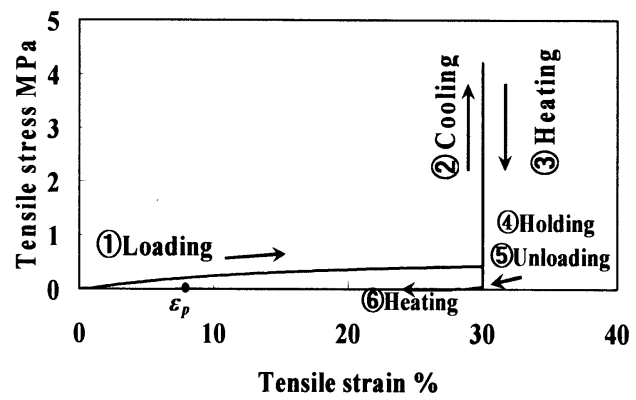

(a) Stress-strain curve

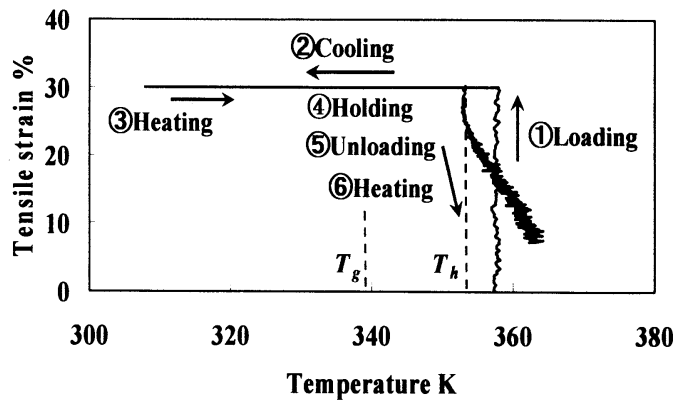

(b) Strain-temperature curve

Fig.2 Stress-strain curve and strain-temperature curve for $\varepsilon_{h}=30 \%, T_{h}=T_{g}+15 \mathrm{~K}$ and $t_{h}=2 \mathrm{~h}$ in tension 


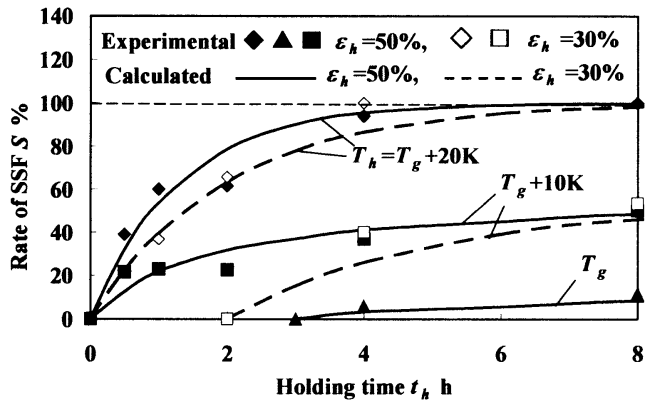

Fig.3 Experimental results between $S$ and $t_{h}$ at $T_{h}=T_{g}$, $T_{g}+10 \mathrm{~K}$ and $T_{g}+20 \mathrm{~K}$ in tension

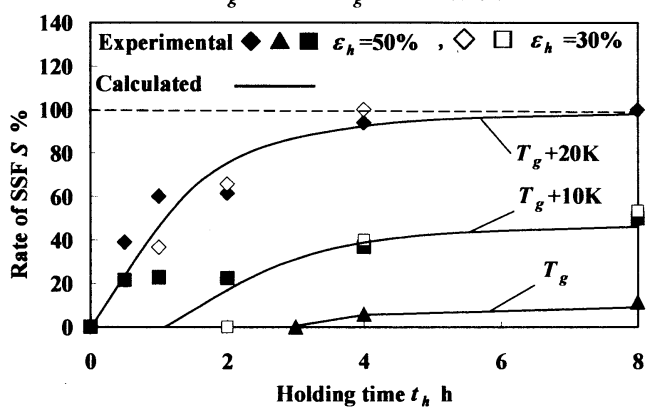

Fig. 4 Calculated results between $S$ and $t_{h}$ in tension

3.1.2 二次国形特性本論文では形状回復性およ び二次賦形特性を利用する実用の点から，ひずみをを 保持した後に $T_{g}+30 \mathrm{~K}$ まで加熱した時に現れる残留ひ ずみ $\varepsilon_{p}$ を非回復ひずみと定義し，二次賦形特性を評価 する.

保持時間 $t_{h}$ 保持温度 $T_{h}$ ，保持ひずみ $\boldsymbol{z}_{h}$ の保持条件 を変えて試験を行った. 得られた非回復ひずみ $\varepsilon_{p}$ から 二次賦形を評価する為に, 二次賦形率 $S$ を次式で定義 する.

$$
S=\frac{\varepsilon_{p}}{\varepsilon_{h}} \quad \cdots \cdot(1)
$$

すなわち, $S$ は $\varepsilon_{h}$ 対する $\varepsilon_{p}$ の割合であり，保持したひ ずみに対する非回復ひずみの割合を表す．実験により 得られた $S$ と保持時間 $t_{h}$ との関係を図 3 に各種の記号 で示す. 図 3 からわかるように, 保持温度が高温にな ればなるほど二次賦形率 $S$ が高くなることがわかる. また, 保持時間 $t_{h}$ が長くなればなるほど $S$ は高くなる. $S$ は $t_{h}$ が増加すると一定值に飽和する傾向を示す。

短時間で現れる二次賦形特性を成形加工一応用する 時には二次賦形率 $S$ の評価式が必要である. 図 3 の特 性から $S$ の $t_{h}$ への依存性は次式で近似される.

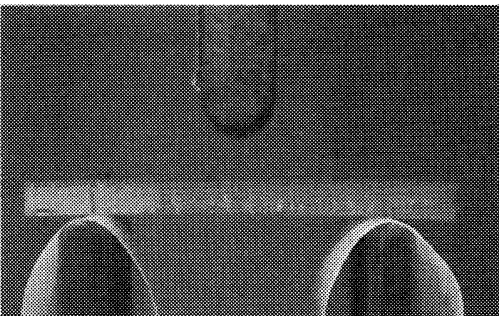

(a) Initial state

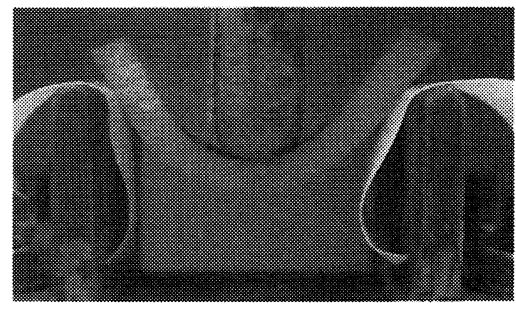

(b) Maximum deflection

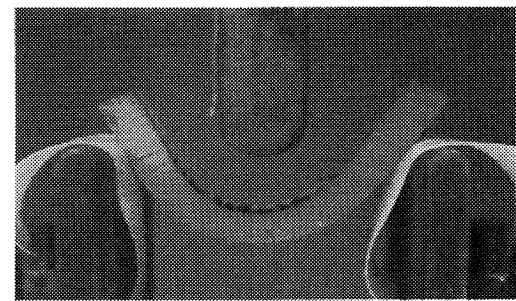

(c) Fixed state by cooling

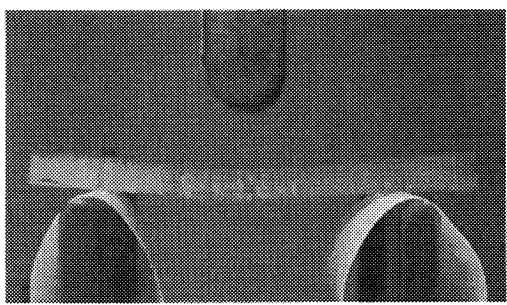

(d) Recovered state by heating

Fig.5 Photographs at various states in bending

$$
S=S_{p}\left(1-e^{-\frac{t_{h}-t_{s}}{c}}\right) \quad \cdots \cdot(2)
$$

ここで, $S_{p}$ は $S$ の飽和值， $t_{s}$ は二次賦形が現れない限 界の時間, $c$ は時定数を表す. $S$ の実験結果の傾向を近 似するこれらのパラメータの值を用い式(2)により計算 した結果を図 3 に电 $=50 \%$ と $30 \%$ の結果をそれぞれ実 線と破線で示す. 図3 からわかるように, $S$ の特性は式 (2)でうまく表せる. 図 3 における $S$ の挙動からわかる ように，二次賦形はひずみ保持温度 $T_{h}$ が高いほど短時 間保持で現れ，二次賦形率 $S$ の值は大きい. $T_{h}$ が低く なり， $T_{g}$ に近づくにつれて，二次賦形が現れるまでの 


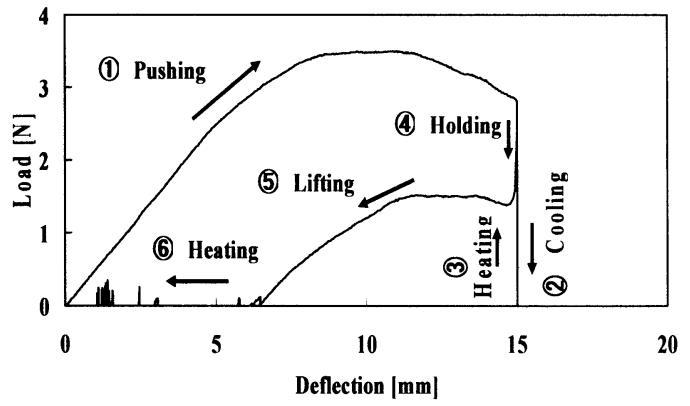

(a) Relationship between load and deflection

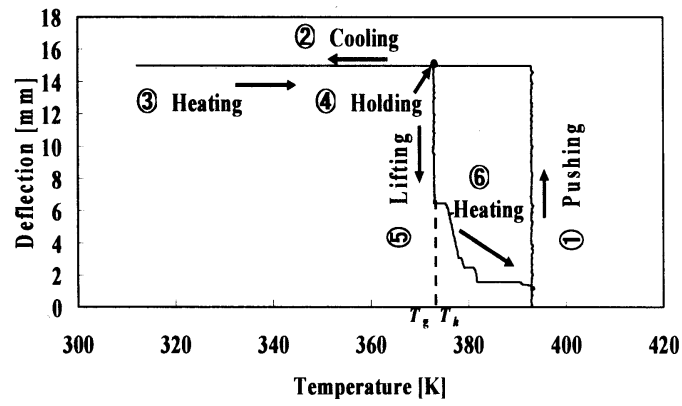

(b) Relationship between deflection and temperature

Fig.6 Load-deflection-temperature relation for $T_{\mathrm{h}}=T_{g}$ and $t_{\mathrm{h}}=4 \mathrm{~h}$ and $y_{h}=15 \mathrm{~mm}$ in bending

保持時間は長くなり， $S$ は小さい. また， $\varepsilon_{h}$ が大きいほ ぞ二次賦形は早く現れる.

これらの傾向からわかるように式(2)に含まれる特性 值は保持温度 $T_{h}$ に依存する. 実験結果を近似するこれ らの特性值を $T_{h}$ の線形関数で表すと次式のようになる.

$$
\left.\begin{array}{l}
S_{p}=0.04\left(T_{h}-T_{g}\right)+0.12 \\
c=-0.26\left(T_{h}-T_{g}\right)+6.6 \\
t_{s}=-0.16\left(T_{h}-T_{g}\right)+2.7
\end{array}\right\} \cdots(3)
$$

式(2)と式(3)により計算した結果を図 4 に実線で示す. 図 4 からわかるように, $S$ の特性は式(2)および(3)でう まく表せる.

このようにSMPのフィルムの引張試験からとॄは 比例し, $T_{g}$ よりも高温で保持を行うと二次賦形現象が 現れることがわかった．またその二次賦形率を $t_{h}$ と $T_{h}$ の関数で表すことができた. $S$ の特性を表すこれらの関 係式は二次賦形を SMP 要素の成形加工に応用する場 合に有用である.

\section{2 曲げにおける形状回復と二次眼形特性}

3.2.1 曲げにおけるたわみ状態 図 5 に $T_{\mathrm{h}}=T_{g}$, $t_{h}=4 \mathrm{~h}$ のシートの 3 点曲け試験におけるシートのたわみ 状態を表す写真を示す. (a) は初期状態, (b) は最大た

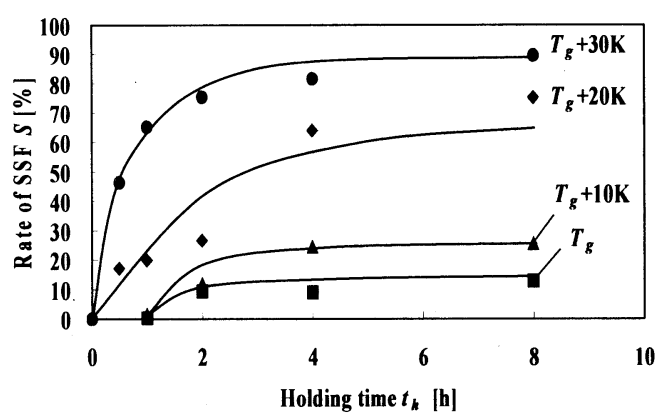

Fig.7 Experimental results between $S$ and $t_{h}$ in bending

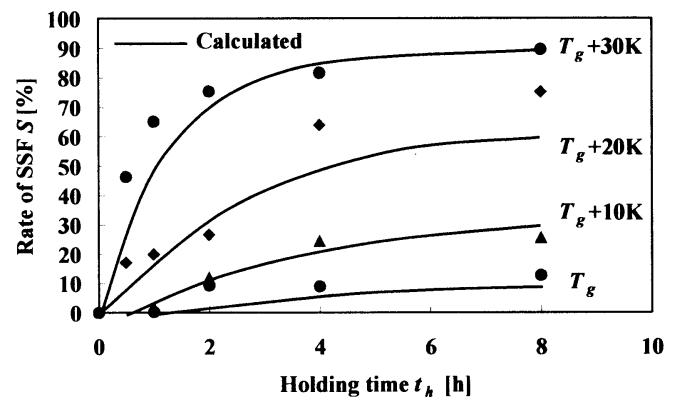

Fig. 8 Calculated results between $S$ and $t_{h}$ in bending

わみ $y_{\text {max }}=15 \mathrm{~mm}$ まで押込み, (c) は室温まで泠却し除 荷, (d)は $T_{g}+20 \mathrm{~K}$ まで加熱した時の写真である. 図 5 からわかるように，(b)の状態から冷却して(c)の状態に なるとき, 変形した形状が固定される. また, 最大た わみの状態で $T_{h}=T_{g}, t_{h}=4 \mathrm{~h}$ の条件で保持した後に, $T_{g}+20 \mathrm{~K}$ まで加熱すると形状が大きく回復する(d).

3.2.2 荷重一たわみ-温度関係 図 6(a)に $T_{h}=T_{g}$, $t_{h}=4 \mathrm{~h}$ のシートの 3 点曲げ試験で得られた荷重-たわみ 曲線を示す. 図 6(a) に示すように, $T_{g}+20 \mathrm{~K}$ で負荷する と，たわみが $10 \mathrm{~mm}$ 近傍で荷重は最大值をとる(1). 最 大たわみ $y_{\text {max }}=15 \mathrm{~mm}$ まで押込んだ後, 冷却を行うと SMPはガラス領域になるため変形した状態を保って固 定され，荷重は消滅する(2)，室温まで泠却後，所定の 保持温度 $T_{h}$ まで加熱し(3), 所定の保持時間 $t_{h}$ で保持を 行う(4). その後, 押込み棒を引上げると $6.5 \mathrm{~mm}$ のたわ みが残留する(5).

図 6(b)にたわみと温度の関係を示す. (1)で負荷を与 え最大たわみ $y_{\text {max }}=15 \mathrm{~mm}$ にした後, 冷却を行う(2). 室 温になったら所定の保持温度 $T_{h}$ まで加熱し(3), 所定の 保持時間 $t_{h}$ で保持を行う (4). その後の除荷で $6.5 \mathrm{~mm}$ の 残留たわみが現れる(5). 無負荷での加熱過程(6)におい てたわみは减少し， $T_{g}+20 \mathrm{~K}$ でたわみは $1.8 \mathrm{~mm}$ になる.

3.2 .3 短時間保持による二次樶形特性曲げを受 ける場合の二次賦形特性を評価するために, 曲げを受 
けた場合の変形状態を規定するシート表面の曲げひず みにより,保持ひずみ后および非回復ひずみ市を定めた. この為に, 図 5 に示した写真から最大たわみの位置に おけるシート中立面の曲率半径 $r$ を求め, 厚さ $t$ のシー 卜表面の曲げひずみ $\varepsilon を \varepsilon=t / 2 r$ により求めた. $y_{\mathrm{h}}=15 \mathrm{~mm}$ のときの表面の曲げひずみ员は $20.8 \%$ あ゙あ.この曲げ

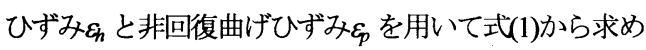
た二次賦形率 $S$ と保持時間 $t_{h}$ の関係を図 7 に示す. 図 7 よりわかるように，保持温度 $T_{g}$ の場合， $t_{h}=1 \mathrm{~h}$ で $S$ は $0.3 \%, t_{h}=8 \mathrm{~h}$ で $S$ は $12.8 \%$ となる. 保持温度 $T_{g}+10 \mathrm{~K}$ の 場合, $t_{h}=1 \mathrm{~h}$ で $S$ は $1.61 \%, t_{h}=8 \mathrm{~h}$ で $S$ は $25.6 \%$ となる. 保持温度 $T_{g}+20 \mathrm{~K}$ の場合, $t_{h}=0.5 \mathrm{~h}$ で $S$ は $17.1 \%, t_{h}=8 \mathrm{~h}$ で $S$ は $75.1 \%$ となる. 保持温度 $T_{g}+30 \mathrm{~K}$ の場合, $t_{h}=0.5 \mathrm{~h}$ で $S$ は 46.4\%, $t_{h}=8 \mathrm{~h}$ で $S$ は 89.6\%となる. これより保 持温度 $T_{h}$ が高くなればなるほど，二次賦形率が高くな ることがわかる. また，保持時間 $t_{h}$ が長くなれば二次 賦形率が高くなる.これは保持温度が高温になるほど, SMP の分子のミクロブラウン運動が活発になり, 分子 の再配列が行われやすくなり, 保持した形状が固定さ れることによる. しかし， $t_{h}=8 \mathrm{~h}$ までの保持条件では二 次賦形率 $S$ は 100\%にはならない.この結果は本実験条 件で得られたものであり, $T_{g}$ の異なる材料, $T_{h}>T_{g}+30 \mathrm{~K}$, $\varepsilon_{n}>50 \%$ の場合についてはさらに検討が必要である.

フィルムの引張の場合と同様に $S$ を式(2)で表す. $S$ の飽和値 $S_{p}$, 二次賦形が現れない限界の時間 $t_{s}$, 時定数 $c$ は保持温度 $T_{h}$ に依存する。実験結果を近似するこれ らの特性值を $T_{h}$ の関数で表すと次式のようになる.

$$
\left.\begin{array}{l}
S_{p}=0.0256\left(T_{h}-T_{g}\right)+0.128 \\
c=-0.175\left(T_{h}-T_{g}\right)+6.5 \\
t_{s}=-0.065\left(T_{h}-T_{g}\right)+1.3
\end{array}\right\} \cdots
$$

式(2)と式(4)により計算した結果を図 8 に実線で示す. 図 8 からわかるように, $S$ の特性は式(2)および(4)でう まく表せる。これらのシートの曲げにおける二次賦形 の特性は, フィルムの引張の場合と同じ傾向を示す.

3.2.4 長時間保持による二次眼形特性 シートの 曲げの長時間保持による二次賦形率 $S$ と保持時間 $t_{h}$ の 関係を図 9 に示す。図9よりわかるように，保持時間 を長くしていくと, $T_{h}=T_{g}+30 \mathrm{~K}$ の場合 $t_{h}=72 \mathrm{~h}$ で, $T_{h}$ $=T_{g}+20 \mathrm{~K}$ の場合 $t_{h}=96 \mathrm{~h}$ で, $T_{h}=T_{g}+10 \mathrm{~K}$ の場合 $t_{h}=96 \mathrm{~h}$ で 二次賦形率 $S$ は $100 \%$ となる. $T_{h}=T_{g}$ の場合 $t_{h}=96 \mathrm{~h}$ で $S$ は95\%となる.

図 10 に長時間保持試験における保持温度 $T_{h}-T_{g}$ と保持 時間 $t_{h}$ の関数としての二次賦形率 $S$ を示す. 図からわ かるように保持温度が下がれば，それぞれの二次賦形

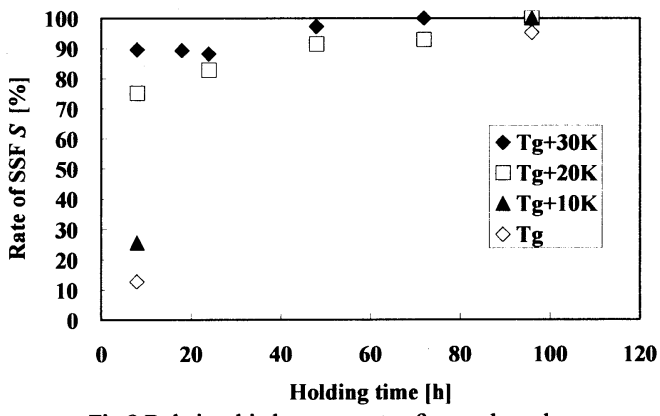

Fig.9 Relationship between rate of secondary-shape forming and holding time in bending

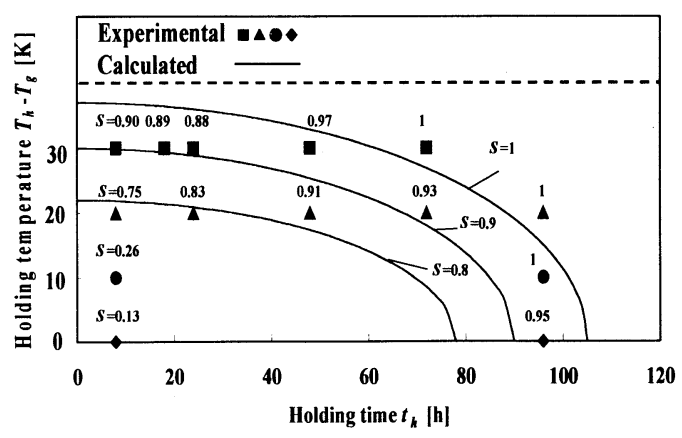

Fig.10 Equi-secondary shape forming rate curve in bending

率 $S$ に達するための保持時間が長くなり, $S$ の等しい点 を結ぶ等二次賦形率曲線は右下がりの傾向になる.こ の等二次賦形率曲線を用いれば，保持条件 $t_{h}$ と $T_{h}$ によ る二次賦形率 $S$ への寄与が一目で評価できる.これら の等二次賦形率を表す関係は次式の棈円で近似するこ とができる.

$$
\frac{t_{h}{ }^{2}}{t_{0}{ }^{2}}+\frac{\left(T_{h}-T_{g}\right)^{2}}{T_{0}^{2}}=1 \cdots(5)
$$

ここで, $t_{0}$ と $T_{0}$ は楕円の長径と短径を示す. このよう に長時間における等二次賦形率曲線は保持時間 $t_{h} お よ$ び保持温度 $T_{h}$ の関数で表すことができる. また, 式(5) で表される等二次賦形率曲線の長径 $t_{0}$ と短径 $T_{0}$ は $S$ に 関して次のようになる.

$$
\left.\begin{array}{l}
t_{0}=135 S-30 \\
T_{0}=75 S-38
\end{array}\right\} \cdots \cdots(6)
$$

式(5)と式(6)による計算結果を図 10 に実線で示す.実線 はそれぞれ二次賦形率 $S$ が 80\%，90\%，100\%の場合を 示している.これから $S$ が 0.8 以上の二次賦形特性は式 (5)と式(6)によりほぼ表せることがわかる.したがって, 
二次賦形特性は等二次賦形率曲線により容易に推算で きる.

\section{4. 結 言}

ポリウレタン系 SMP について高温でひずみを与え， そのひずみを種々の熱・学条件下で保持し，その後 の加熱によるひずみの回復と二次賦形特性を調べた. 実験ではフィルムの引張りとシートの 3 点曲げについ て形状回復および二次賦形の基本特性に対するひずみ 保持条件の影響を検討した. 得られた結果は次の通り である.

(1) 保持温度が高くなれば, 二次賦形が生じやすくなる. また，保持温度が同じでも保持時間が長くなると，二 次賦形はより生じやすくなる.

(2) $T_{g}$ 以上の保持温度では保持温度と保持時間の増加 に伴い非回復ひずみが徐々に増加する. 得られた結果 から二次賦形率を表す関係式を提案した.

(3)形状回復性を利用するためにはひずみは $T_{g}-10 \mathrm{~K}$ 以 下の温度で保持し, 二次賦形を SMP 要素の成形加工に 利用するためには $T_{g}+20 \mathrm{~K}$ 以上の温度でひずみを保持 することが有効である.

(4) 曲げを受ける SMP シートに関してガラス転移領域 以上の温度で長時間保持を行った場合, 0.8 以上の二次 賦形率は, 保持時間と保持温度の関数で規定する等二 次賦形率曲線により推算できる，等二次賦形率曲線は 楕円でほぼ近似できる.

終わりに, 本研究を行うに当り実験に協力された愛 知工業大学の学生諸君に感謝する. 材料の作製と有益
な議論をいただいた中菱エンジニアリング(株)の三輪 典生氏に感謝する.また, 本研究は日本学術振興会の 科学研究費補助金・基盤研究(C)の補助を受けたことを 記し謝意を表す.

\section{参考文获}

(1) Otsuka, K. and Wayman, C. M. (ed), Shape Memory Materials, (1998), pp. 203-219, Cambridge University Press, Cambridge.

(2) Sun, Q.P. (ed), IUTAM Symp. on Mechanics of Martensitic Phase Transformation in Solids, (2002), pp.79-86, Netherlands, Kluwer-Academic.

(3) Hayashi, S., Properties and applications of polyurethane series shape memory polymer, Int. Prog. Urethanes, 6, (1993), pp.90-115.

(4) Takahashi, T., Hayashi, N. and Hayashi, S., Structure and properties of shape-memory polyurethane block copolymers, J. Appl. Polym Sci., 60,(1996), pp.1061-1069.

(5) Ishizawa, J., Imagawa, K., Yoshikawa, J., Hayashi, S. and Miwa, N., Research on applicability of shape memory polymers (SMPs) to inflatable and deployable shape structure, Proc. $7^{\text {th }}$ Japan Int. SAMPE Symp. and Exhibition, (2001), pp.295-298.

(6) Tobushi, H. Matsui, R., Hayashi, S., and Shimada, D., The influence of shape-holding conditions on shape recovery of polyurethane-shape memory polymer foams, Smart Mater. Struct., 13 (2004), pp.881-887.

(7) Tobushi, H., Okumura, K., Hayashi, S. and Ito, N., Thermomechanical constitutive model of shape memory polymer, Mech. Mater., 33 (2001), pp.545-554.

(8) Tobushi, H., Hayashi, S. and Kojima, S., Mechanical properties of shape memory polymer of polyurethane series (Basic characteristics of stress-strain-temperature relationship), JSME Int. J., I, 35 (1992), pp.296-302.

(9) Ferry, J. D., Viscoelastic Properties of Polymers, (1980), pp.224-263, John Wiley \& Sons, New York. 